\title{
EVAPORATION TIME OF DROPLETS CONTAINING THIAMETHOXAM AND ADJUVANTS ON HYDROPHILIC, HYDROPHOBIC AND LIPOPHILIC SURFACES UNDER DIFFERENT AIR RELATIVE HUMIDITIES
}

\author{
TEMPO DE EVAPORAÇÃO DE GOTAS CONTENDO TIAMETOXAM E \\ ADJUVANTES DEPOSITADAS EM SUPERFÍCIES HIDROFÍLICA, HIDROFÓBICA \\ E LIPOFÍLICA EM DIFERENTES UMIDADES RELATIVAS DO AR
}

\author{
Olinto LASMAR ${ }^{1}$; João Paulo Arantes Rodrigues da CUNHA ${ }^{2}$ \\ 1. Engenheiro Agrônomo, Instituto de Ciências Agrárias - ICIAG, Universidade Federal de Uberlândia - UFU, Uberlândia, MG, Brasil; \\ 2. Professor, Doutor, ICIAG - UFU, Uberlândia, MG, Brasil. jpcunha@iciag.ufu.br
}

\begin{abstract}
The efficacy of pesticide applications is related to the spread and evaporation time of the droplets deposited on the target. This study evaluates the evaporation of spray droplets containing thiamethoxam and adjuvants on different surfaces and at different levels of relative air humidity. A climate controlled chamber was set up with a digital microscope to produce images of droplet evaporation. Three surfaces (hydrophilic, lipophilic and hydrophobic), five solutions (water, thiamethoxam, thiamethoxam + mineral oil, thiamethoxam + vegetable oil, thiamethoxam + surfactant) and three air humidity levels $(45 \%, 60 \%$ and $75 \%)$ were evaluated. The surface tension of these solutions was also measured. It was found that all of the insecticide solutions reduced surface tension, that air humidity, target surface and spray formulation influenced spray evaporation and that surfactants reduced the evaporation time of droplets on natural lipophilic surfaces.
\end{abstract}

KEYWORDS: Application technology. Additive. Spray deposition. Volatilization. Spraying.

\section{INTRODUCTION}

The efficacy of an application of a plant protection product is related to its effective deposition and the consequent absorption of active ingredients, which is in turn related to the spread and evaporation time of the droplets deposited on the target (VILELA; ANTUNIASSI, 2013).

The droplets produced by hydraulic sprayers are subject to drift from the moment they exit the spray nozzle. Drift is defined as the loss of plant protection products, as droplets or vapor, from the target either during or after application. Upon reaching the target, the droplets spread, thereby increasing coverage, and remain until evaporating. Droplet size, relative air humidity, leaf structure, product formulation and adjuvant interaction influence the evaporation of droplets from the target surface (YU et al., 2009b). Fragmenting the spray solution into droplets increases the surface area of the liquid, which leads to greater evaporation (CORRÊA, 1985; MATTHEWS, 1992). This effect is stronger at lower air humidity levels since evaporation is faster in dry environments. Larger droplets minimize losses to drift and evaporation, but also decrease coverage relative to finer droplets.

The other important factor that influences in the evaporation refers to the interaction between droplet and surface. In general, spray droplets cover large areas on leaf surfaces with little epicuticular wax development. Long hydrocarbon chains are hydrophobic whereas alcohols and acids are relatively hydrophilic (ZHU et al., 2010). Additionally, trichomes on the leaf surface can intercept droplets and prevent them from reaching the epidermis. If the deposition surface is hydrophobic (waxy) contact will be limited and the droplets will be spherical. However, if the surface is more hydrophilic, the drop will spread and may even form a uniform film. Good leaf wettability depends on the composition of the epidermis in which attraction to water needs to be stronger than the surface tension of the water itself (IOST; RAETANO, 2010).

After evaporation, leaves may stop absorbing the product that has been applied (RAMSEY et al., 2005). Similarly, according to Yu et al. (2009b) and $\mathrm{Xu}$ et al. (2011), active ingredients may crystalize after evaporation, which impedes absorption but which might be ameliorated by longer evaporation times. This lengthening would increase the efficiency of the application (RAMSEY et al., 2006); however, as evaporation times increase, the potential for runoff also increases, which would lower the efficiency of the application (YU et al., 2009a), especially when application rate is considered.

One way of increasing evaporation time is by adding adjuvants to the spray solution. Some compounds have properties that can reduce 
evaporation losses. Studies by Zhu et al. (2008) report that evaporation times decreased when a surfactant was added to an insecticide spray, which is contrary to the effect of adding a drift reducing compound that increases evaporation time.

Given these points and Brazilian climatic conditions, studies on plant protection application technologies that address droplet evaporation from various types of products and also address interactions with adjuvants are scarce and deserve attention. Thus, it is of utmost importance to determine the environmental behavior of plant production products such as thiamethoxam. Neonicotinoid insecticides are widely used in agriculture but calls for restrictions on their use have intensified due to environmental concerns.

Thus, the objective of this study was to evaluate the evaporation of spray droplets containing thiamethoxam (with or without adjuvants) from hydrophilic, hydrophobic and lipophilic surfaces, correlated with relative humidity.

\section{MATERIAL AND METHODS}

The work was conducted in the Laboratory of Agricultural Mechanization at Federal University
LASMAR, O.; CUNHA, J. P. A. R.

of Uberlândia (Minas Gerais, Brazil). The evaluations were based on the methodologies of Zhu et al. (2008) and Vilela and Antuniassi (2013), and consisted of determining droplet evaporation from different surfaces (hydrophilic, hydrophobic and lipophilic) by quantifying evaporation time. It was also determined the surface tension of the solutions for subsequent correlations.

A completely randomized experiment with 5 repetitions was set up in a $5 \times 3$ factorial model for each surface type: five spray solutions (water, insecticide, insecticide + mineral oil, insecticide + vegetable oil, insecticide + anti-evaporating agent) and three relative humidity levels $(45 \%, 60 \%$ and $75 \%)$.

The treatments consisted of an insecticide from the neonicotinoid group by itself and mixed with three different adjuvants to simulate agricultural spray solutions. Specifically, the pesticide was thiamethoxam (Actara $\left.{ }^{\circledR} 250 \mathrm{WG}\right)$ and the adjuvants were: mineral oil (Nimbus ${ }^{\circledR}$ ), vegetable oil (Veget'oil $\left.{ }^{\circledR}\right)$ and a surfactant (InTec $\left.{ }^{\circledR}\right)$ (Table 1). Manufacturer recommendations were followed for product concentrations and water was used as a control.

Table 1. Description of treatments (products and respective concentrations).

\begin{tabular}{lccc}
\hline Product & $\begin{array}{c}\text { Concentration } \\
\text { (commercial product) }\end{array}$ & $\begin{array}{c}\text { Recommendation } \\
\text { (manufacturer) }\end{array}$ & $\begin{array}{c}\text { Spray solution } \\
\text { concentration } \\
(\% \mathrm{v} / \mathrm{v} ; \mathrm{m} / \mathrm{v})\end{array}$ \\
\hline $\begin{array}{l}\text { Thiamethoxam } \\
\text { Paraffinic mineral oil } \\
\text { (aliphatic hydrocarbon) }\end{array}$ & $250 \mathrm{~g} \mathrm{~kg}^{-1}$ & $\begin{array}{c}1000 \mathrm{~g} \mathrm{ha}^{-1} \\
0.50 \mathrm{~L} \mathrm{~L} \mathrm{100} \mathrm{L}^{-1}\end{array}$ & 0.40 \\
$\begin{array}{l}\text { Vegetable oil } \\
\text { (esters of fatty acids) }\end{array}$ & $928 \mathrm{~g} \mathrm{~L}^{-1}$ & $\begin{array}{c}\text { solution } \\
\text { Su L } 100 \mathrm{~L}^{-1}\end{array}$ & 0.50 \\
$\begin{array}{l}\text { Surfactant } \\
\text { (nonylphenol ethoxylate) }\end{array}$ & $124.4 \mathrm{~g} \mathrm{~L}^{-1}$ & $\begin{array}{c}0.05 \mathrm{~L} 100 \mathrm{~L}^{-1} \\
\text { solution }\end{array}$ & 0.50 \\
\hline
\end{tabular}

The spray solutions were prepared with distilled water just before use and then placed in 100 $\mathrm{mL}$ volumetric flasks. The flasks allowed the solutions to be agitated before use to avoid problems related to solution stability such as precipitation and phase separation. Surface tension was determined using a bench tensiometer (Kruss, model K6) with a platinum ring and the $\mathrm{Du}$ Nouy method (DOPIERALA; PROCHASKA, 2008). The test measures tension on the ring, which is affixed to the end of a flexible rod, as it is placed on a sample surface and pressed until undergoing repulsion. The tensiometer was calibrated with distilled water.
The evaporation experiments consisted of determining evaporation times under different levels of relative humidity (RH): $45 \%, 60 \%$ and $75 \%$. These evaluations were performed within a climate controlled chamber (Quimis, model Q315C21) to help control temperature and relative humidity and to eliminate undesirable air currents. Air temperature was maintained at $25^{\circ} \mathrm{C}$ throughout the experiment.

Images were captured via a digital microscope/camera (Dino-Lite Digital Microscope, model AM413ZT) that was positioned over the surface where the drops were deposited. The camera had a resolution of 1.3 Mega pixels, a USB interface 
and 200x magnification. The software provided by the manufacturer (Dino Capture 2.0) was capable of capturing images in real time.

Three surface types were evaluated: hydrophilic (glass slides), hydrophobic (plastic film) and lipophilic (freshly cut sugarcane - Saccharum officinarum L. - leaves) The glass slides and plastic film were first cleaned with cotton soaked in alcohol, afterwards with water and then dried with a paper towel. These surfaces were changed at each data collection point.

Zhu et al. (2008) showed that evaporation behavior was similar for different drop sizes (246 to $886 \mu \mathrm{m})$. Therefore, a standardized drop size was used (diameter $=337 \mu \mathrm{m}$, volume $=0.02 \mu \mathrm{L}$ ). These drops were generated using a precision microsyringe connected to a dispenser (Hamilton model $700.5 \mathrm{C}$, capacity $=0.5 \mathrm{uL}$, resolution $=0.01$ $\mathrm{uL})$.

Evaporation times in seconds were determined by observations via the camera. The time was determined as the interval between droplet deposition and droplet extinction. The initial and final moments of evaporation were registered by camera images captured during evaporation and the
LASMAR, O.; CUNHA, J. P. A. R.

interval calculated by subtracting the time of the final image (complete evaporation) from the time of the first image (droplet deposition).

The first statistical analysis was a data assumption test. Levene and Shapiro Wilk's tests were used to determine homogeneity of variances and normality of residuals, respectively (SPSS statistical software, v. 17.0). The data were not transformed because all assumptions were met at 0.01 level of significance. Subsequently, the data were submitted to analysis of variance and means were compared by the Tukey test at 0.05 level of significance.

\section{RESULTS AND DISCUSSION}

Surface tension varied significantly among the various spray solutions (Table 2). Water had the highest surface tension $\left(75.2 \mathrm{mN} \mathrm{m}^{-1}\right)$ and thiamethoxam + mineral oil had the lowest $(37.7$ $\left.\mathrm{mN} \mathrm{m}^{-1}\right)$. All of the adjuvants reduced surface tension; however, the surface tension values of the solutions with vegetable oil and with surfactant were not significantly different from that of the insecticide by itself.

Table 2. Surface tension $\left(\mathrm{mN} \mathrm{m}^{-1}\right)$ of various spray solutions.

\begin{tabular}{lc}
\hline Solution & Surface Tension $\left(\mathrm{mN} \mathrm{m}^{-1}\right)$ \\
\hline Water & $75.2 \mathrm{a}$ \\
Water + Thiamethoxam & $43.9 \mathrm{~b}$ \\
Water + Thiamethoxam + Mineral Oil & $37.7 \mathrm{c}$ \\
Water + Thiamethoxam + Vegetable Oil & $42.0 \mathrm{~b}$ \\
Water + Thiamethoxam + Surfactant & $42.7 \mathrm{~b}$ \\
\hline CV $(\%)$ & 2.4 \\
\hline F (solutions) & $658.3^{* *}$ \\
\hline ans followed by the same lower case letters are not significantly different from each other (Tukey, 0.05$).{ }^{* *}$ Significant at 0.01.
\end{tabular}

Cunha et al. (2010) also concluded that all evaluated adjuvants (soybean methyl ester oil, polymethylsiloxane polyether copolymer, esters of fatty acids with glycol, and aliphatic hydrocarbons) reduced the surface tension of spray solutions relative to water, thus corroborating the results of the present study.

A revision of the literature on plant surface wettability performed by Taylor (2011) found that retaining spray on the target is significant for the biological effectiveness of plant protection products, especially on surfaces on which fixation is difficult. The author also found that the properties of the spray droplets must be optimized to avoid significant losses, underlining the importance of knowing the surface tensions of spray solutions. In general, reducing surface tension increases the wetted surface area, which in turn interferes with the duration of droplet evaporation.

The data on droplet evaporation from a hydrophilic surface (glass slide) shows that there is link between the composition of a spray solution and relative humidity. The thiamethoxam + mineral oil solution had the longest evaporation time at all three relative humidity levels $(45 \%, 60 \%$ and $75 \%)$ (Table 3). Solutions containing vegetable oil and surfactant had the shortest evaporation times. Lower humidity levels reduced droplet lifetime, indicating that especially dry days or dry periods may reduce product absorption. 
Table 3. Mean evaporation times of droplet (s) on hydrophilic surfaces (glass slides) for various spray solutions and relative humidity levels.

\begin{tabular}{lccc}
\hline \multirow{2}{*}{ Solution } & \multicolumn{3}{c}{ Relative Humidity (\%) } \\
\cline { 2 - 4 } & $17.8 \mathrm{bB}$ & 60 & 75 \\
\hline Water & $15.2 \mathrm{bC}$ & $23.0 \mathrm{bA}$ & $24.6 \mathrm{bA}$ \\
Thiamethoxam & $19.8 \mathrm{cB}$ & $23.2 \mathrm{bcA}$ \\
Thiamethoxam + Mineral Oil & $23.6 \mathrm{aC}$ & $35.6 \mathrm{aB}$ & $57.2 \mathrm{aA}$ \\
Thiamethoxam + Vegetable Oil & $10.8 \mathrm{cB}$ & $19.0 \mathrm{cA}$ & $20.2 \mathrm{cdA}$ \\
Thiamethoxam + Surfactant & $11.0 \mathrm{cC}$ & $15.6 \mathrm{~dB}$ & $19.0 \mathrm{dA}$ \\
\hline $\mathrm{CV}(\%)$ & \multicolumn{3}{c}{7.7} \\
\hline $\mathrm{F}$ (solution) & \multicolumn{3}{c}{$452.8^{* *}$} \\
\hline $\mathrm{F}$ (humidity) & $360.3^{* *}$ \\
\hline F (solutions * humidity) & \multicolumn{3}{c}{$59.9^{* *}$} \\
\hline
\end{tabular}

Means followed by the same lower case letters in columns and upper case letters in rows are not significantly different (Tukey, 0.05).

**Significant at 0.01 .

The addition of mineral oil produces a film around the droplet that modifies evaporation. Zhu et al. (2010) showed that surfactants reduce evaporation times. However, these authors studied pilose and waxy surfaces. The authors conclude their paper by emphasizing that evaporation is dependent on surface type. Waxy surface, for example, impedes surface wetting, which in turn impedes the attraction between water and the hydrophilic surface. Other important factor is that there were big differences between the surfactant products.
The solution with thiamethoxam + mineral oil also had the longest evaporation times on the hydrophobic surface (plastic film), which could boost the efficiency of the active ingredient (Table 4). Again, lower humidity led to faster droplet extinction. At $45 \%$ relative humidity, vegetable oil and the surfactant did not lengthen evaporation time over that of the solution containing only insecticide. However, these adjuvants did lengthen evaporation times at $60 \%$ and $75 \%$ humidity, but not to the extent of mineral oil.

Table 4. Mean evaporation times of droplet (s) on hydrophobic surfaces (plastic film) for various spray solutions and relative humidity levels.

\begin{tabular}{lccc}
\hline \multirow{2}{*}{ Solution } & \multicolumn{3}{c}{ Relative humidity (\%) } \\
\cline { 2 - 4 } & $52.6 \mathrm{bC}$ & 60 & 75 \\
\hline Water & $35.0 \mathrm{cC}$ & $74.8 \mathrm{aB}$ & $95.6 \mathrm{bA}$ \\
Thiamethoxam & $81.6 \mathrm{aB}$ & $82.8 \mathrm{cB}$ & $70.6 \mathrm{dA}$ \\
Thiamethoxam + Mineral Oil & $34.8 \mathrm{cC}$ & $58.0 \mathrm{bB}$ & $132.8 \mathrm{aA}$ \\
Thiamethoxam + Vegetable Oil & $34.0 \mathrm{cC}$ & $55.0 \mathrm{bcB}$ & $85.0 \mathrm{cA}$ \\
Thiamethoxam + Surfactant & \multicolumn{4}{c}{8.1} \\
\hline CV (\%) & \multicolumn{4}{c}{$181.8^{* *}$} \\
\hline F (solutions) & \multicolumn{4}{c}{$463.7^{* *}$} \\
\hline F (humidity) & $7.8^{* *}$ \\
\hline F (solutions * humidity) & \multicolumn{3}{l}{} \\
\hline Means followed by the same lower case letters in columns and upper case letters in rows are not significantly different (Tukey, 0.05).
\end{tabular}

Droplet evaporation times on the hydrophobic surface were longer than those on the hydrophilic surface. Similar results were found by $\mathrm{Yu}$ et al. (2009b) and Zhu et al. (2008). Attraction between the hydrophilic surface and the droplet increases the contact area, which results in higher evaporation rates. According to Kissmann (1998), a water repellant surface reduces the contact area and leads to a more spherical droplet.
The behavior of droplets on the natural lipophilic surface (sugarcane leaf) differed from that of droplets on the artificial hydrophilic and hydrophobic surfaces (Table 5). On the sugarcane leaf, the cuticle covers the periclinal outer walls of the epidermal cells, forming a coating of a lipid nature that is the major route for spray solution uptake. Additionally, sugarcane leaves have trichomes that interfere with droplet deposition (FERREIRA et al., 2005). Glass slides have a 
microstructure (highly hydrophilic) that can influence the behavior of droplets.

Table 5. Mean evaporation times of droplet (s) on lipophilic surfaces (sugarcane leaves) for various spray solutions and relative humidity levels.

\begin{tabular}{lccc}
\hline \multirow{2}{*}{ Solution } & \multicolumn{3}{c}{ Relative humidity (\%) } \\
\cline { 2 - 4 } & $34.6 \mathrm{aC}$ & 60 & 75 \\
\hline Water & $24.2 \mathrm{bB}$ & $49.8 \mathrm{aB}$ & $61.6 \mathrm{aA}$ \\
Thiamethoxam & $8.6 \mathrm{cB}$ & $14.8 \mathrm{bB}$ & $40.2 \mathrm{bcA}$ \\
Thiamethoxam + Mineral Oil & $20.8 \mathrm{bB}$ & $28.6 \mathrm{bAB}$ & $23.8 \mathrm{dA}$ \\
Thiamethoxam + Vegetable Oil & $22.6 \mathrm{bC}$ & $33.0 \mathrm{bB}$ & $30.8 \mathrm{cdA}$ \\
Thiamethoxam + Surfactant & \multicolumn{3}{c}{18.7} \\
\hline CV (\%) & \multicolumn{3}{c}{$63.9^{* *}$} \\
\hline F (solutions) & $58.9^{* *}$ \\
\hline F (humidity) & $1.86^{*}$ \\
\hline F (solutions * humidity)
\end{tabular}

Means followed by the same lower case letters in columns and upper case letters in rows are not sigifcantly different (Tukey, 0.05). *, **Significant at 0.05 and 0.01 , respectively.

Behavior was similar to that of the other surfaces regarding relative humidity.

The solution containing thiamethoxam + mineral oil produced the shortest evaporation times. According to Kissmann (1998), oils reduce water evaporation while on the trajectory to the target because water droplets emulsified with oil evaporate more slowly. However, it is also necessary to consider the evaporation process on surfaces that are more complex than air. Contact with these surfaces cause the droplets to spread out, which increases contact area.

Spray solutions containing insecticides and adjuvants reduced droplet lifetime compared to water. This may be due to the surface tension of the solutions. Table 2 shows that all of the insecticide solutions reduced surface tension, which increases wetted area and exposes the droplets to evaporation. Surfactants can decrease bond energy between water molecules, which reduces the surface tension of the spray droplets. Lower surface tension in turn, decreases the contact angle of the droplets on the leaf surface, allowing greater surface contact with the leaf.

According to Gimenes et al. (2013), droplet evaporation times are inversely proportional to the size of the wetted area and significantly reduced when surfactant adjuvants are added. However, $\mathrm{Xu}$ et al. (2010) reports that in addition to the wetted area, other factors that interfere with evaporation should also be considered such as surface characteristics, the presence of wax and wax composition. These factors shed light on the differences in evaporation observed for the three surfaces evaluated in the present study. This is specifically true for mineral oil, suggesting that it is not possible to generalize about the effect of adjuvants on droplet evaporation.

The formulation of each commercial emulsifiable oil varies since manufacturers may use different types of emulsifiers and while product labels indicate the proportion of adjuvant used, they do not specify the exact emulsifier used. Emulsifer type determines some of the physical-chemical characteristics of the spray solution such as surface tension (QUEIROZ et al., 2008).

The efficacy of pesticide applications is often related to droplet dispersal and evaporation and can be lessened if the active ingredient is not spread evenly over the target (XU et al., 2010). Nevertheless, while better dispersal improves the uniformity of coverage, it may also produce droplets with shorter lifetimes.

\section{CONCLUSIONS}

Relative humidity, target surface structure and spray formulation influenced the evaporation of droplets from the surface.

Adding mineral oil to the spray solution increased evaporation times from artificial hydrophobic and hydrophillic surfaces, but reduced evaporation times from a natural lipophillic surface. The results using the artificial surfaces must be analyzed carefully.

The use of surfactants reduced the evaporation time of droplets deposited on sugarcane leaves. 


\section{ACKNOWLEDGMENTS}

The authors thank CAPES (National Council for the Improvement of Higher Education)
LASMAR, O.; CUNHA, J. P. A. R.

and $\mathrm{CNPq}$ (National Council for Scientific and Technological Development) for financial support of research project.

RESUMO: A eficácia de uma aplicação de produto fitossanitário está relacionada ao espalhamento e ao tempo de evaporação das gotas depositadas sobre o alvo. O presente trabalho teve como objetivo avaliar a evaporação de gotas depositadas em distintas superfícies, a partir de caldas contendo tiametoxam e adjuvantes, em diferentes umidades relativas do ar. Foi montada uma estrutura a partir de uma câmara climática de condições controladas e um microscópio digital para análise de imagens da evaporação de gotas. Foram avaliadas, em três superfícies (hidrofílica, hidrofóbica e lipofílica), cinco soluções (água, tiametoxam, tiametoxam + óleo mineral, tiametoxam + óleo vegetal, tiametoxam + espalhante) e três umidades relativas do ar $(45 \%, 60 \%$ e $75 \%)$. Também foi realizada análise da tensão superficial destas soluções. Com base nos resultados obtidos, todas as soluções inseticidas reduziram a tensão superficial da calda; a umidade relativa do ar, a estrutura da superfície alvo e a formulação da calda do produto fitossanitário influenciaram a evaporação de gotas em superfície; e o uso de surfactantes reduziu o tempo de evaporação de gotas depositadas em superfície natural lipofílica.

PALAVRAS-CHAVE: Tecnologia de aplicação. Aditivos. Deposição de calda. Volatilização. Pulverização.

\section{REFERENCES}

CORRÊA, H. G. Redução da evaporação de gotículas contendo herbicida, com emprego de oxietileno docosanol. Bragantia, Campinas, v. 44, n. 1, p. 159-171, 1985. http://dx.doi.org/10.1590/S000687051985000100013

CUNHA, J. P. A. R.; ALVES, G. S.; REIS, E. F. Efeito da temperatura nas características físico-químicas de soluções aquosas com adjuvantes de uso agrícola. Planta Daninha, Viçosa, v. 28, n. 3, p. 665-672, 2010.

DOPIERALA, K.; PROCHASKA, K. The effect of molecular structure on the surface properties of selected quaternary ammonium salts. Journal of Colloid and Interface Science, London, v. 321, n. 1, p. 220-226, 2008. http://dx.doi.org/10.1016/j.jcis.2008.01.049

FERREIRA, E. A.; DEMUNER, A. J.; SILVA, A. A.; SANTOS, J. B.; VENTRELlA, M. C.; MARQUES, A. E.; PROCÓPIO, S. O. Composição química da cera epicuticular e caracterização da superfície foliar em genótipos de cana-de-açúcar. Planta Daninha, Viçosa, v. 23, n. 4, p. 611-619, 2005.

GIMENES M. J.; ZHU, H.; RAETANO, C. G.; OLIVEIRA R. B. Dispersion and evaporation of droplets amended with adjuvants on soybeans. Crop Protection, London, v. 44, n. 2, p; 84-90, 2013.

IOST, C. A. R.; RAETANO, C. G. Tensão superficial dinâmica e ângulo de contato de soluções aquosas com surfatantes em superfícies artificiais e naturais. Engenharia Agrícola, Jaboticabal, v. 30, n. 4, p. 670-680, 2010.

KISSMANN, K. G. Adjuvantes para caldas de produtos fitossanitários. In: GUEDES, J. V. C.; DORNELLES, S. B. Tecnologia e segurança na aplicação de agrotóxicos. Santa Maria: Departamento de Defesa Fitossanitária, Sociedade de Agronomia de Santa Maria, 1998. p. 39-51.

MATTHEWS, G. A. Pesticides Application Methods. 2nd. ed. England: Longman Scientific \& Technical, 1992. $405 \mathrm{p}$.

QUEIROZ, A. A.; MARTINS, J. A. S.; CUNHA, J. P. A. R. Adjuvantes e qualidade da água na aplicação de agrotóxicos. Bioscience Journal, Uberlândia, v. 24, n. 4, p. 8-19, 2008. 
RAMSEY, R. J. L.; STEPHENSON, G. R.; HALL, J. C. A review of the effects of humidity, humectants, and surfactant composition on the absorption and efficacy of highly water-soluble herbicides. Pesticide Biochemistry and Physiology, San Diego, v. 82, n. 2, p. 162-175, 2005.

http://dx.doi.org/10.1016/j.pestbp.2005.02.005

RAMSEY, R. J. L.; STEPHENSON, G. R.; HALL, J. C. Effect of humectants on the uptake and efficacy of glufosinate in wild oat (Avena fatua) plants and isolated cuticles under dry conditions. Weed Science, Champaign, v. 54, n. 2, p. 205-211, 2006.

TAYLOR, P. The wetting of leaf surfaces. Current Opinion in Colloid \& Interface Science, London, v. 16, n. 4, p. 326-334, 2011. http://dx.doi.org/10.1016/j.cocis.2010.12.003

VILELA, C. M.; ANTUNIASSI, U. R. Evaporação de gotas de caldas contendo fungicida e adjuvantes depositadas em superfície. Energia na Agricultura, Botucatu, v. 28, n. 2, p. 65-73, 2013.

XU, L.; ZHU, H.; OZKAN, H. E.; BAGLEY, W. E.; DERKSEN, R. C.; KRAUSE, C. R. Adjuvant effects on evaporation time and wetted area of droplets on waxy leaves. Transactions of the ASABE, St. Joseph, v. 53, n. 1, p. 13-20, 2010. http://dx.doi.org/10.1002/ps.2122

XU, L.; ZHU, H.; OZKAN, H. E.; BAGLEY, W. E.; KRAUSE, C. R. Droplet evaporation and spread on waxy and hairy leaves associated with type and concentration of adjuvants. Pest Management Science, West Sussex, v. 7, n. 67, p.842-851, 2011.

YU, Y.; ZHU, H.; OZKAN, H. E. Evaporation of pesticide droplets on surface under various relative humidity conditions. Journal of ASTM International, West Conshohocken, v. 6, n. 1, p. 1-8, 2009a.

http://dx.doi.org/10.1520/stp48706s

http://dx.doi.org/10.1520/jai101491

YU, Y.; ZHU, H.; FRANTZ, J. M.; REDING, M. E.; CHAN, K. C.;OZKAN, H. E. Evaporation and coverage area of pesticide droplets on hairy and waxy leaves. Biosystems Engineering, London, v. 104, n. 3, p. 324-334, 2009b. http://dx.doi.org/10.1016/j.biosystemseng.2009.08.006

ZHU, H.; YU, Y.; OZKAN, H. E.; DERKSEN, R. C.; KRAUSE, C. R. Influence of spray additives on droplet evaporation and residual patterns on wax and wax-free surfaces. St. Joseph: ASABE, 2008. Paper No. 083752.

ZHU, H., YU, Y.; XU, L.; OZKAN, H. E.; KRAUSE, C. R. Evaporation time and spread area of adjuvantamended droplets on waxy and hairy leaves. In: ANNUAL CONFERENCE ON LIQUID ATOMIZATION AND SPRAY SYSTEMS, 22., 2010, Cincinnati, Proceedings... Cincinnati: Ilass, 2010. 11 p. 